Marvin P. Miracle (Stanford): Research on the role of maize in tropical African agriculture and diets in the Belgian Congo and N. Rhodesia.

Laurence Salomon (Boston): Research on the European immigration to South Africa since I 910 (Union of South Africa).

The following have been awarded fellowships for studies in political science at American universities:

Willard $R$. Johnson: Program of African studies at School of Advanced International Studies, Johns Hopkins University.

William Worthy: Program of directed study relating to Africa and general reading at Boston University.

\title{
Réorganisation de l'I.F.A.N.
}

L'Évolution politique de l'Afrique française et, en particulier, la disparition des organismes fédéraux de l'ancienne A.O.F. devait entraîner, pour l'I.F.A.N., de profonds changements de structure. Cet Institut, qui était jusqu'ici un 'Service', dont les crédits étaient inscrits au budget fédéral, a été récemment transformé, par décret, en Institut d'Université, rattaché à l'Université de Dakar et fonctionnant sous l'autorité d'un Conseil présidé par le Recteur de cette dernière. En même temps, l'I.F.A.N. construisait, sur le campus universitaire, un vaste bâtiment destiné à abriter ses services généraux (bibliothèque, etc.), ses sections d'étude et ses collections, à l'exception de la Section d'Ethnographie destinée à demeurer dans le bậtiment actuel, où sera installé un Musée.

La construction d'un nouvel I.F.A.N. sur le campus permettra un large regroupement des activités africanistes locales, d'autant plus heureux au moment où vont se développer dans les Facultés elles-mêmes les enseignements africains et, dans une certaine mesure, la recherche; la Faculté des Lettres a déjà un enseignement géographique et sociologique en partie orienté vers l'Afrique; dès I960, la linguistique à son tour et, peut-être, les langues et civilisations musulmanes se verront inscrites au programme.

Il va sans dire que le personnel enseignant comme les étudiants désirant se livrer à la recherche trouveront dans la proximité de l'I.F.A.N. la riche documentation accumulée depuis plus de vingt ans par ce dernier et l'aide la plus substantielle.

Si le sort de l'ancien I.F.A.N. fédéral a été réglé par un rattachement universitaire qui le fait dépendre désormais, au point de vue des crédits, du budget de l'Éducation Nationale (Paris), les Centres I.F.A.N. des divers Territoires appartiennent désormais, administrativement et budgétairement, aux nouvelles Républiques et n'entretiennent plus avec Dakar que des rapports d'ordre scientifique. Le Centre de Guinée est devenu 'Institut National de Recherches et de Documentation '.

\section{[Communicated by Professor Th. Monod, Director of I.F.A.N.]}

\section{The Restatement of African Law}

THE School of Oriental and African Studies of the University of London has initiated a comprehensive scheme for the study and restatement of African customary law, as found in the English-speaking territories of Africa. The Project has received generous financial assistance from the Nuffield Foundation to cover its work during the first three years of its operation.

The economic and social problems of African countries have become increasingly urgent, more especially in the spheres of land tenure and succession, the family, marriage, and the status of women. The East African Royal Commission 1953-5 emphasized the paramount need for reform of the land tenure and succession systems if economic development was to 
proceed at full speed; while in West Africa also the governments are beginning to tackle these difficult and complex aspects of the law.

The Project will involve the collection and analysis of existing material on the customary law, and the preparation of a series of publications which would restate the principles of customary law as they vary from tribe to tribe or ethnic group to ethnic group within the assigned regions of study. For this purpose Africa has been divided into three regions: West Africa; East Africa; Central-Southern Africa; and within these regions the primary emphasis will be placed on the British or Commonwealth territories. To restrict the field of investigation, the Project will be limited in the first place to the customary law relating to marriage, the family, land tenure, and succession.

Preliminary draft bibliographies, including all published and unpublished sources of information relating to the customary law in the selected regions, will be prepared and circulated for comments and additions to all those having special knowledge of the subject in Africa and elsewhere. Regional restatements will then be prepared on the basis of the bibliographies and other material available. The form of the Restatement will be somewhere between that of the American Restatements of the Law of Torts, Contracts, \&c., and the Digest of Customary Law in the Punjab made by Sir William Rattigan and his successors. The Restatement will, it is hoped, reveal the extent to which local divergences and variations in the customary law obtain, and will note modern changes and developments in the substance and administration of the customary law. The African Marriage Survey, conducted by the International African Institute under the direction of Dr. Arthur Phillips, was a notable forerunner in this field.

The Project cannot succeed, however, without the co-operation of other interested persons and bodies in Africa and elsewhere, and the fullest mutual assistance is envisaged between those engaged on the Restatement and governmental and academic agencies in Africa. International collaboration with French, Belgian, and other scholars will also be of vital importance. The experience now being gained at the School in the recording and analysis of material on the customary law will, it is hoped, be of value to others; and the card-indexes and files of the Restatement will be made available to other accredited research workers in this field.

The Project will be under the particular direction of Dr. A. N. Allott, Lecturer in African Law at the School and Editor of the Journal of African Law.

\section{Current Research at the Rhodes-Livingstone Institute}

THE research work of the Institute is proceeding on a broad front. In the field of urban and peri-urban social survey, Dr. Bettison was able to complete the necessary field work before his recent appointment to a teaching post at the University of Queensland. Since he joined the Institute in January 1957, Dr. Bettison and the Institute's team of assistants have conducted surveys in and around Blantyre-Limbe, Lusaka, and, to a lesser degree, Salisbury. One of the most valuable aspects of the work was a Poverty Datum Line study, conducted in these three towns, using identical techniques and the same personnel; in these circumstances the material collected is particularly valuable for a comparative study. Several Communications arising from this work have already been published and further Communications and a Paper are in course of preparation.

Another urban study, the first to be conducted among the European population of the Federation, has started in Salisbury, where P. MacEwan is studying the integration of European immigrants into Southern Rhodesian society. The co-operation of the authorities concerned has been most gratifying, as has the response to the questionnaires issued; the distribution and collection of these has involved the temporary employment of a considerable team of assistants. 